Teresa JAKUBOWSKA

Jan BARAŃSKI

Warszawa

\title{
Głos kobiet: jaka ma być nowa Europa?
}

R ACJA Polskiej Lewicy nawiązała ostatnio współpracę z organizacja$\mathbf{R}_{\text {mi kobiecymi w Europie. Kobiety mobilizują się w obliczu ożywienia }}$ przez Angelę Merkel sprawy konstytucji europejskiej. Jej pierwsza wersja przygotowana przez Konwent pod przewodnictwem byłego prezydenta Francji Valery'ego Giscard d'Estaing została odrzucona przez Francuzów i Holendrów. Było wiele zarzutów pod adresem eurokonstytucji m.in. w części dotyczącej podstawowych praw człowieka nie zabezpieczała ona wystarczająco praw kobiet i ich zrównania z prawami mężczyzn.

Trzeba podkreślić, że w Europie Zachodniej działalność wielu organizacji religijnych, zwłaszcza muzułmańskich, które domagają się wyjęcia spod jurysdykcji państw Unii Europejskiej obywateli tego wyznania w zakresie prawa rodzinnego, w kwestiach edukacyjnych i obyczajowych, mobilizuje kobiety do walki. Z kolei aktywność kościołów chrześcijańskich po upadku ZSRR w niektórych państwach - nowych członkach UE i zdecydowany wpływ kościołów na życie polityczne, edukację i system prawny, doprowadziły do utraty praw przez kobiety. Kobiety zrozumiały, że żadne prawa nie są im dane raz na zawsze. Przykład Polski uświadomił im, że utrata tych praw może się odbyć niezwykle szybko i niemal niepostrzeżenie.

Owocem naszej współpracy są poniższe dezyderaty feministyczne do nowej konstytucji europejskiej. Bazą tekstu były dezyderaty Europejskiej Inicjatywy Feministycznej sformułowane na międzynarodowej konferencji w Atenach w dniach 4-7 maja 2006 roku oraz ankiety wypełnione przez organizacje kobiece w wielu krajach nie tylko członkach Unii Europejskiej. Mój wkład polegał na usystematyzowaniu materiału, uściśleniu niektórych punktów oraz dodaniu pkt 7 i 8 . Autorzy tych dezyderatów wnosili różne elementy oparte na doświadczeniach w swoich krajach. Wszyscy jednak byli absolutnie zgodni co do stwierdzenia podstawowego: powszechne prawa czlowieka, a więc równe prawa kobiet i mężczyzn są możliwe tylko w państwie świeckim, takim, w którym kościoły są oddzielone od państwa. 


\section{Dezyderaty feministyczne do Traktatu Konstytucyjnego Unii Europejskiej}

Kobiety - dyskryminowane przez wszystkie religie - żądają, by świeckość, pojęta jako rozdział kościołów od sfery publicznej, stała się jedną z podstawowych zasad budowy nowej Europy i żeby Państwa członkowie Unii Europejskiej zobowiązały się do wprowadzenia i egzekwowania poniższych zasad w swoich krajach.

1. Żadna religia nie może być uznana za religię „państwową”. Organizacje kościelne muszą być całkowicie oddzielone od struktur państwowych i nie mogą instytucjonalnie wpływać na sferę polityczną. Organizacje kościelne muszą same się finansować. Żadna organizacja kościelna nie może być wspierana i dotowana przez państwo, z wyjątkiem obiektów sakralnych, uznanych przez państwo za dzieła sztuki szczególnej wagi.

2. Sprzeciwiamy się finansowaniu kościołów z budżetu Unii Europejskiej, czyli z pieniędzy podatników państw członków. Unia Europejska powinna wprowadzić procedury zmniejszania dotacji UE dla państw, które finansują kościoły ze swoich budżetów.

3. Zabronione jest nauczanie jednej ideologii religijnej w szkołach publicznych. Różne nurty religijne, jako fenomen historyczny i społeczny powinny natomiast znaleźć miejsce na lekcjach historii w szkołach publicznych. Nauczanie to powinno pozostać w gestii państwa.

4. Państwa są zobowiązane do zrównania praw kobiet i mężczyzn oraz do egzekwowania tych praw w zakresie dostępu do edukacji, praw majątkowych, w tym dziedziczenia, prawa do opieki nad dziećmi, dostępu do opieki lekarskiej, równych praw na rynku pracy i szeroko pojętych praw obywatelskich. Egzekwowanie tych praw ma zapobiegać seksizmowi, czyli przedstawianiu kobiet jako podrzędnej kategorii ludzkiej, występującemu w ideologiach religijnych, szerzeniu pogardy do kobiet, propagandzie przeciw samostanowieniu kobiet oraz fałszywych wyobrażeń o szkodliwości antykoncepcji czy aborcji.

5. Należy wprowadzić do programów szkolnych w edukacji publicznej wychowanie przeciwko seksizmowi i wychowanie do równości od najmłodszych lat.

6. Na świat powinny przychodzić tylko dzieci chciane. W tym celu państwa zapewnią - zgodnie z najnowszymi osiagnięciami nauki - po- 
wszechną edukację seksualną od najmłodszych lat, dostosowaną do wieku, powszechny dostęp do środków antykoncepcyjnych, do badań prenatalnych, do aborcji i sterylizacji na żądanie.

7. Państwa wprowadzą przepisy skutecznie zapobiegające przemocy w rodzinie i zrównujące prawa dziecka $\mathrm{z}$ dorosłymi w zakresie nietykalności osobistej. Sądy nie mogą oddalać pozwów w tych sprawach z powodu niskiej szkodliwości czynu. Przemoc w rodzinie powinna być wystarczającym powodem rozwodu.

8. Państwa wprowadzą procedury obowiązujące policję i służby medyczne w wypadku zgłoszenia się ofiar gwałtu: m.in. instrukcję postępowania z ofiarą; narzędzia, zabezpieczające ślady przestępstwa, umożliwiające identyfikację sprawcy; udostępnienie każdej kobiecie - ofierze gwałtu najskuteczniejszego antykoncepcyjnego preparatu postkoitalnego. Gwałt powinien być ścigany $\mathrm{z}$ urzędu.

9. Małżeństwo cywilne oraz prawo do rozwodu cywilnego muszą stać się normą w Europie, dostępną także dla kobiet ze środowisk muzułmańskich. Dyskryminacja osób żyjących w związkach partnerskich oraz par i rodzin homoseksualnych musi być zwalczana za pomocą ustawodawstwa antydyskryminacyjnego, umożliwiającego m.in. rejestrację tego rodzaju związków w urzędach państwowych.

10. Państwa nie mogą uznawać i tolerować na swoim terytorium obcych kodeksów rodzinnych i cywilnych, dyskryminujących kobiety. Państwa muszą zmienić umowy bilateralne, które przewidują taką tolerancję. Prawo rodzinne i cywilne nie może wywodzić się z żadnych dogmatów i zasad religijnych. Wolność wyznania, poszanowanie kultur, religii i tradycji nie może być pretekstem do gwałcenia praw kobiet. W szczególności państwa powinny ścigać z całą surowością prawa: „honorowe” zabójstwa kobiet, proceder okaleczania narządów płciowych czy małżeństwa wyznaniowe dzieci.

11. Organizacje kościelne muszą respektować prawo kraju, w którym działają. Uprzywilejowany status tych organizacji wobec Unii Europejskiej i jej państw-członków musi zostać zlikwidowany.

12. Kobiety i mężczyźni muszą mieć identyczny dostęp do wszystkich funkcji społecznych i politycznych. W tym celu państwa są zobowiązane do wprowadzenia zasady parytetu wynikającego z proporcji liczebności kobiet i mężczyzn w danym kraju. 
Bazą tekstu były dezyderaty Europejskiej Inicjatywy Feministycznej Ateny z maja 2006 r. oraz kwestionariusze, wypelnione przez organizacje feministyczne wielu krajów europejskich.

marzec 2007

\section{Summary}

The author states that formally Poland is not a religious state; however, the country evidently shows signs of a religious state. To support this argument the author points out many examples: the influence of the church on the legal system, education - this is the reason why women are discriminated (anti-abortion law), the favourable treatment of the clergy by the courts, religious instructions at public schools and kindergartens, the absence of school lessons on the human body and it's pro-creation purposes, situation in the media, the growing influence of the clergy on the army, the funding of the church from the state budget. 